\title{
Study of Some Physiological and Pathological Aspects of Feral Queen's Reproductive System in Iraq
}

\author{
$\begin{array}{lll}\text { H. J.Kadhim } & \text { D. H.Jassim } & \text { T. A. Abid }\end{array}$ \\ Coll. of Vet. Med. / Univ. of Al-Qadisiya
}

\begin{abstract}
The present study is carried out to investigate some aspects of reproduction in Iraqi feral cats. Sixty blood samples and female genital specimens from sexually mature queens were trapped during the period from December 2008 to December 2009.During the entire study period, the results showed that incidence rate of follicular phase was $24.56 \%$ and the highest incidence was in Winter $62.5 \%$, while no follicular activity was noted in animals during Autumn. The hormonal assay showed that the mean of the estradiol $-17 ß$ in 14 follicular phase animals was $47.5 \mathrm{pg} / \mathrm{ml}$, while The dominance of vaginal epithelial cells in 14 estrus queens were nucleated superficial cells $61.5 \%$.The incidence of luteal phase was $29.82 \%$ and the highest incidence was in Spring 56.66\%, and the average of corpora lutea per animal was $4.7 \%$ and the incidence rate of pregnant queens was $19.29 \%$, with high incidence in Summer $33.33 \%$ wih no pregnant queens was captured in Winter. The implantation rate was $86.06 \%$ and the transuterine migration of embryos was observed in incidence rate $27.27 \%$ and all transuterine migration of embryos was occurred in animals with $100 \%$ implantation rate . The maximum number of embryos that migrate was 2 /animal. The incidence rate of pseudopregnancy $11.76 \%$, and characterized by present of active corpora lutea on ovaries, with slight enlargement of uterus and uterine tube .

In all animals with diestrus the mean of plasma progesterone level was $48 \mathrm{ng} / \mathrm{ml}$, and the cell comprising the vaginal smear include intermediate cells $47 \%$ parabasal cells $45 \%$ and nucleated cells 5\% .The anestrus phase was recognized in incidence rate $36.84 \%$ and the highest incidence of anestrus phase was noted in Autumn 75\%, Cells comprising the vaginal smear in anestrus queens include intermediate cells $87.9 \%$, parabasal cells $8.6 \%$,nucleated superficial cells $2.7 \%$, anucleated superficial cells $0.8 \%$.The pathological study was revealed 3 out of 60 queens with gross reproductive systems abnormalities, with incidence rate $5 \%$, these cases include paraovarian cyst, follicular cysts and pyometra.
\end{abstract}

\section{Introduction}

Domestic cat (Felis catus) is one of seven species of the genus Felis (a group of small size cats), which is a part of Felids ,which include in addition to domestic cat, lion, tiger, cougar and many others (1). Scientifically, domestic cats are used as laboratory animals due to the fact that they have some physiological features more in common with human than the laboratory rabbit or other rodent, hence they have extremely used in behavioral and biomedical researches particularly in neurological signs

\section{Materials and Methods}

\section{Animals}

The study was carried out in three governorates include ,Babylon, Al-diwaniya and An-najaf from December 2008 to
(2).Recently, the domestic cat (Felis catus) is a useful model for studying comparative biology of the Felidae family and for developing assisted reproductive techniques for propagating related, endangered species (3). For all above, and due to the rarity of the available references about the feline reproductive system particularly in Iraq, the present study is designed to spotlight on some physiological features and pathological abnormalities of Iraqi feral queens.

December 2009, 60 mature female cat were captured by local made feral cat trap, each captured animal was anaesthetized according to (2) ,then the anaesthetized animal was 
examined clinically with recording of obtained data in special examination card .

\section{Blood Samples}

Sixty blood samples collected from cephalic vein according to (4) the collected blood was poured in labeled plastic plain tube ,and placed in room temperature for 2 hours ,the serum collected by Pasteur's pipette after centrifugation at 3000/rpm for 10 minutes and stored in plastic container at $-20^{\circ} \mathrm{C}$. The stored sera were send private laboratory for determination of estradiol 17$\beta$ and progesterone hormones by ELISA apparatus (Bio active DNM-9602/Germany) with specific kit ( Abbot laboratories USA) and according to the instruction of the company .

\section{Vaginal Smears}

The vaginal smears was carried out according to the method that is recommended by (5), briefly by introducing a cotton- tipped swab moistened with sterile saline in to the vestibule and caudal vagina with avoiding of clitoral fossa The cotton tipped swab was rolled onto a glass slide ,allowed to air- dry and stained with Giemsa stain. The correlation between vaginal cytology and stages of the estrus was interpreted according to (6).

\section{Female Reproductive Tract Samples}

Sixty samples of the female reproductive tract are collected directly after euthanizing of animal, the female reproductive tract was taken entirely from the ovaries to the vulva ,the non pregnant samples classified in to reproductive tract with or without pathological changes. After detection of physiological evidences of different phases of estrous cycle in non pregnant samples, a longitudinal incision was made along whole tract to expose the luminal surface for examination to observe any abnormalities or pathological changes, if reproductive systems showed clear gross pathological lesions, small piece $1 \mathrm{~cm}^{3}$ were fixed in $10 \%$ buffered neutral formalin for 3 days for histopathological examination according to (7), while another piece were taken for bacteriological examination, the bacteriological isolation and identification performed according to (8). The reproductive tracts with pregnancy were examined to record the number of fetuses per animal, number of fetuses in each uterine horn and the number of corpora lutea were obtained,the transuterine migration of embryos and implantation rate were recorded according to (9) as following :The number of ovulation was estimated by number of $\mathrm{CL}$ in the ovaries . The number of CL was determined by external examination of the ovary with active CL which being round shape with a $3 \mathrm{~mm}$ diameter and raised $2 \mathrm{~mm}$ above surface of the ovary, and transuterine migration of embryos was estimated to have occurred prior to implantation when the number of fetuses in a given horn was more than the number of CL present in the ipsilateral ovary. The implantation rate considered as $100 \%$ when the number of total CL was equal to the total number of fetuses.

\section{Statistical Analysis}

The results was analyzed statistically by chi square test and student's test to determine any significant variation between different means(10).

\section{Physiological study A.Follicular Phase}

The incidence rate of follicular phase was $4.56 \%$ ( 14 out of 57of non pregnant pathological changes free queens). The highest incidence was in Winter $62.5 \%$,followed by Spring and Summer in percentage $44.4 \%$ and $33.3 \%$ respectively,

\section{Results}

while no follicular activity was noted in animals during Autumn, figure 1. According to the months of study, the highest incidence was in the February $100 \%$ and the lowest was in the August, while it was absent in September, October ,November and April , and all follicular activity was observed in animals above 1 years old. 
Figure (1) reveal the incidence of follicular phase in different seasons

The size of recorded follicles ranged $0.5-2 \mathrm{~mm}$, and the number was ranged between $1-3$ in the same ovary. Out of 47 observed follicles, 27 were present in right ovaries and 20 in the left ovaries. The results showed that the uterus shape was differ according to size of folliclels ,the uteri of queens with follicles less than $1 \mathrm{~mm}$ were slightly enlarged and congested, with straight uterine horns, while the uterine horns were Spiral in shape if the follicles larger than $1 \mathrm{~mm}$ figure 2 .

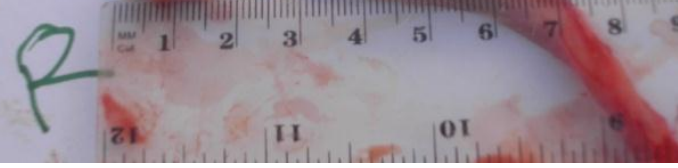

Figure(2) reveal the spiral appearance of uterus in follicular phase

The hormonal assay showed that the blood level of the estradiol $17-\beta$ in 14 follicular phase animals was $47.5 \mathrm{pg} / \mathrm{ml}$, ranged from $25-70 \mathrm{pg} / \mathrm{ml}$, while The percentage and range of vaginal epithelial cells of parabasal cells, intermediate cells, nucleated superficial cells and anucleated superficial cells were $.92 \%(0-3), 12.21$ $\%(0-25), 61.5 \%(6-88)$ and $27.71 \%(4-88)$ respectively.

\section{B. Luteal phase}

The luteal phase was recognized in 17 out of 57 non pregnant pathological change free queens, with incidence rate $29.82 \%$. The highest incidence was in Spring $56.66 \%$,followed by Summer and Autumn in percentage $41 \%$ and $20 \%$ respectively, while it was $6.66 \%$ in Winter, figure 3. According to the months of study, the highest incidence of luteal phase cases was in the April $80 \%$ and the lowest was in the January $20 \%$, while it was absent in February, October ,November and December .The average of corpora lutea per animal was 4.7 $\% \pm 0.12$ (Mean $\pm \mathrm{SE}$; range 2-5)with approximately equal distribution between right and left ovaries as $2.41 \% \pm 18$ (Mean \pm $\mathrm{SE}$; range $0-5)$ in the right ovary vs. $2.35 \% \pm$ 0.58 (Mean $\pm \mathrm{SE}$; range 0-9) in the left ovary .The number of corpora lutea per ovary was same in 3 queens $(17,81 \%)$, greater in right ovary in 7 queens $(41.17 \%)$ and greater in left ovary in 7 queens (41.17\%) . 


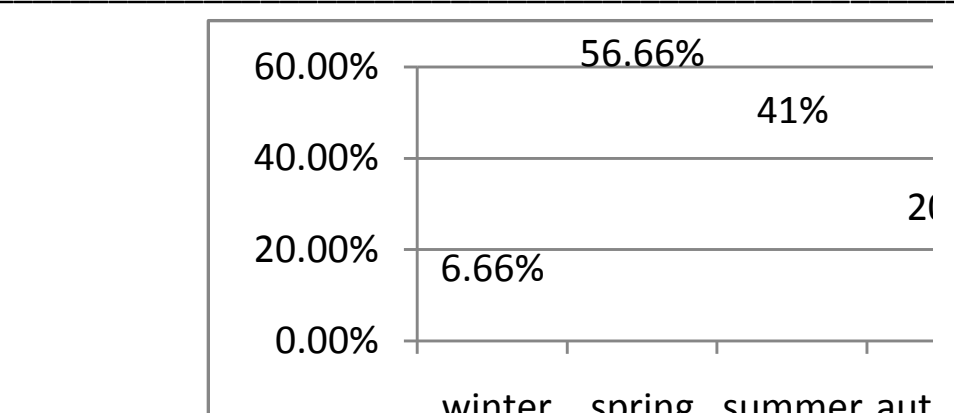

Figure (3) reveal the incidence of luteal phase in different seasons

The animals with this phase were gathered into 4 groups which describe as following :

\section{Recently ovulated queen:}

only one queen was recorded as recently ovulated, it has 2 corpus hemorrhagicum on the right ovary with 3 corpus hemorrhagicum on the left ovary figure 4 ,the oviduct and uterus were markedly enlarged and congested and The estimated estradiol $17-\beta$ and progesterone were 16 $\mathrm{pg} / \mathrm{ml}$ and $2 \mathrm{ng} / \mathrm{ml}$ respectively .

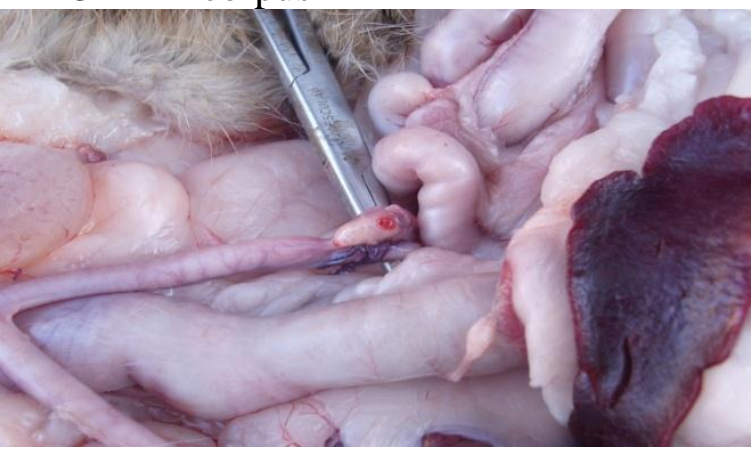

Figure (4) reveal the corpus hemorhhagicum in recently ovulated cat (arrow)

\section{Pregnant queens}

The incidence rate pregnancy was $19.29 \%(11 / 57)$,the highest incidence was in Summer $33.33 \%$,followed by Spring and Autumn in incidence rate $28.57 \%$ and $25 \%$ respectively, while no pregnant cat was captured in Winter figure 5. According to months, the highest incidence of pregnancy was observed in March $50 \%$,followed by
July ,September ,August ,June, April and May in incidence rate $40 \%, 40 \%, 33.33 \%$ ,25\%,20\% and $20 \%$ respectivel. The number of fetuses per each uterine horn was same in $7 / 11$ queens $(63.63 \%)$, greater in right uterine horn in $2 / 11$ queens $(18.18 \%)$ and greater in left uterine horn in $2 / 11$ queens $(18.18 \%)$.

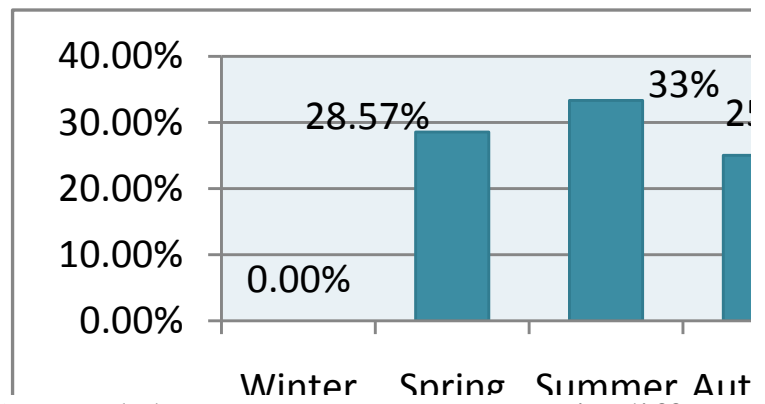

Figure (5) reveal the pregnancy percentage in different seasons

According to $100 \%$ ovulation rate, the implantation rate was $86.06 \%$, and it was
$100 \%$ in $6 / 11$ queens, $80 \%$ in $1 / 11$ queens , $75 \%$ in $2 / 11$ queens , $66.66 \%$ in $1 / 11$ queens 
and $50 \%$ in $1 / 11$ queens $(9.09 \%)$. The transuterine migration of embryos was observed in 3/11 queens with incidence rate $27.27 \%$ table 1 . All transuterine migration of embryos was occurred in animals with $100 \%$ implantation rate , and the maximum number of embryos that migrate per animal was 2 ,in the first queen, two embryos were migrated from right to left uterine horn figure 6 , in the second queen one embryo migrated from right to left uterine horns ,while in the third queen one embryo was migrated from left to right.

Table (1) reveal the relationship between number of corpora lutea, number of fetuses

\begin{tabular}{|c|c|c|c|}
\hline CL/animal & $\begin{array}{c}\text { No } \\
\text {.of } \\
\text { cats }\end{array}$ & $\begin{array}{l}\text { Average } \\
\text { fetus } \\
\text { no.(range) }\end{array}$ & $\begin{array}{c}\text { Implantation } \\
\text { rate } \%\end{array}$ \\
\hline 2 & 3 & $2(1-2)$ & 100 \\
\hline 3 & 3 & $3(1-3)$ & 100 \\
\hline 4 & 2 & $3(2-4)$ & 75 \\
\hline 5 & 1 & $4(-)$ & 80 \\
\hline 6 & 1 & $4(-)$ & 66.66 \\
\hline 8 & 1 & 4 & 50 \\
\hline
\end{tabular}

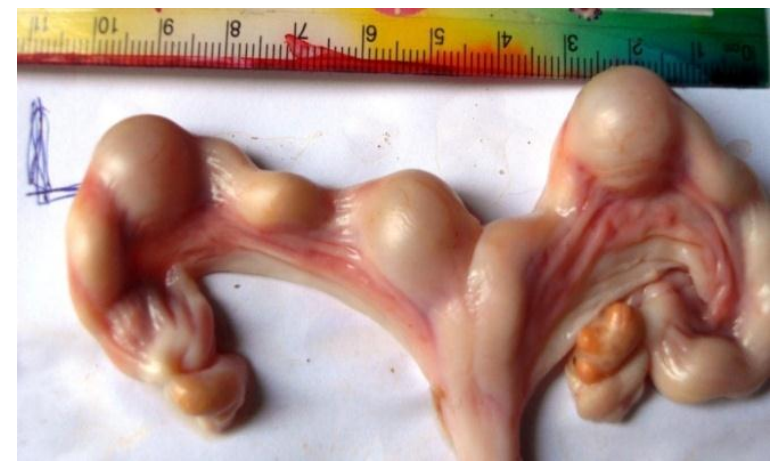

Figure (6) reveal the migration of 2 embryos from right to left uterine horn

\section{Pseudopregnant queens}

The pseudopregnancy was noted in 2out of 17 queens $(11.76 \%)$, the first queen has only 2 active corpora lutea on the right ovary, while the other queen has 2 active corpora lutea on each ovary, the uterus and the uterine tube enlarged slightly. The means of length and diameter of right and left uterine horn were $45 \times 8 \mathrm{~mm}$ and 47.5 $\times 8 \mathrm{~mm}$ respectively, while the means of length and diameter of uterine body were $21.25 \times 6.5 \mathrm{~mm}$.In both pregnant and pseudopregnant animals, the mean of plasma progesterone concentration was $48 \mathrm{ng} / \mathrm{ml}$ (range 22-56) , and the cell comprising the vaginal smear in diestrus cats (mean percentage followed by range) included intermediate cells ( $47 \%$; 18-78) parabasal cells $(45 \% ; 12-82)$, anucleated superficial cells $(0 \%)$,nucleated cells $(5 \% ; 0-5)$.

\section{Queens with involuted uterus}

The involution was noted in 3out of 17 queens with incidence rate $(17.64 \%)$, all these queens were lactating, and had inactive corpora lutea on their ovaries ,the uteri were straight and markedly dilated.The mean \pm SE of length and diameter of right and left uterine horn were $45.66 \times 12 \mathrm{~mm}$ and $40 \times 11.66 \mathrm{~mm}$ respectively, while the means of length and diameter of uterine body were $21 \times 6.66 \mathrm{~mm}$ respectively.

\section{Anestrus phase}

The anestrus phase was recognized in 26 out of 57 pathological free queens, with 
incidence rate $36.84 \%$.The highest incidence of anestrus phase was noted in Autumn $86.66 \%$, followed by Winter ,Summer and Spring in incidence rate $46.66 \%, 20 \%$ and $7.14 \%$ respectively, figure
7. According to the months, the highest incidence of the anestrus phase cases was in October and November $100 \%$ and the lowest was in May and July 20\%, while it was absent in February and March.

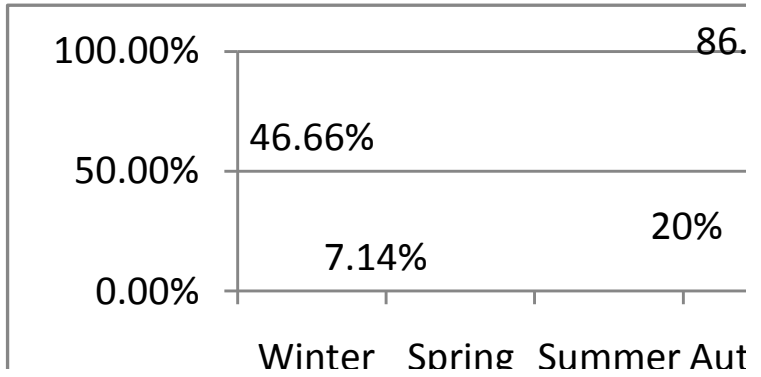

Figure (7) reveal the mean of the anestrus phase according to the seasons

In all observed animals with anestrus phase the ovaries were entirely smooth ,and the mean of uterine horns measurements was at the minimum of all recorded measurements.The mean $\pm \mathrm{SE}$ of length and diameter of right and left uterine horn were $50.5 \pm 1.54 \times 3.2 \pm 0.6 \mathrm{~mm}$ and $54.65 \pm 1.87$ $\times 11.66 \pm 1.45 \mathrm{~mm}$ respectively , while the means \pm SE of length and diameter of uterine body were $16.2 \pm 2.73 \times 4.5 \pm 0.45$ respectively.Cells comprising the vaginal smear in anestrus queens (Mean percentage followed by range )included intermediate cells $87.9 \%(50-100 \%)$, parabasal cells $8.6 \%$ $(0-50 \%)$,nucleated superficial cells $2.7 \%(0-$ $22 \%)$, anucleated superficial cells $0.8 \%(0-$ $2 \%)$.

\section{Pathological Study}

During the study period, out of 60 only 3 queens with gross reproductive systems abnormalities were observed, with incidence rate $5 \%$,these cases were described as following :

\section{- Case (1):Parovarian(Periovarian) Cyst}

One queen with parovarian cyst was captured in this study, this queen was above one year old and weigh $5 \mathrm{~kg}$, the clinical examination revealed that she was healthy. After dissecting the animal a large parovarian cyst was located on the left ovary , it was lobulated, thin walled cyst filled with clear fluid (about $6 \mathrm{ml}$ ), this cyst was surround the ovary entirely, figure 8 . The ovary and uterine horns was normal grossly .The right ovary was with previous ovarian activity, with 1 small follicle on its surface. The histpathological examination of the ovary with the parovarian cyst reveal normal microscopical structure of the ovary and oviduct .

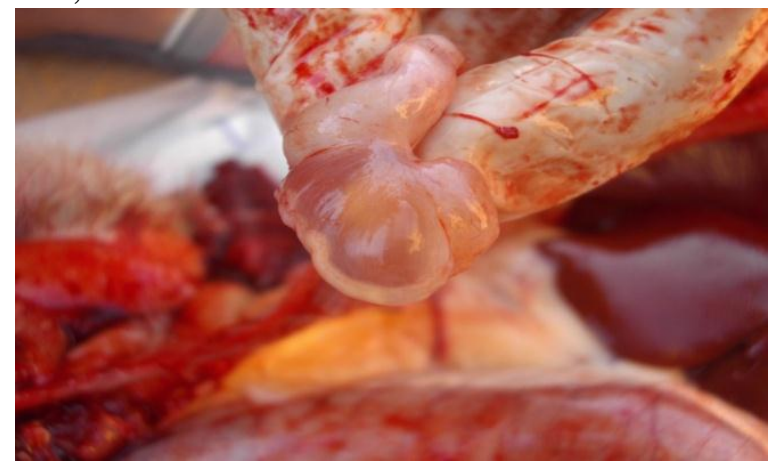

Figure (8) reveal lobulated parovarian cyst 


\section{- Case (2): Follicular Cyst}

Only one queen in this study was reported with follicular cyst. The queen was over one year old and weight about $4.5 \mathrm{~kg}$ ,the clinical examination revealed that the queen was healthy, after dissecting the animal ,a follicular cyst was found on the left ovary, thin walled cyst, filled with clear fluid ,5mm in diameter, the ovaries and uterine horns were normal grossly ,Figure 9.The histopathological examination of the ovary with the follicular cyst reveal normal micrscopical structure of the ovary with present of relatively large follicles as well as normal sized follicles ,figure 10 .

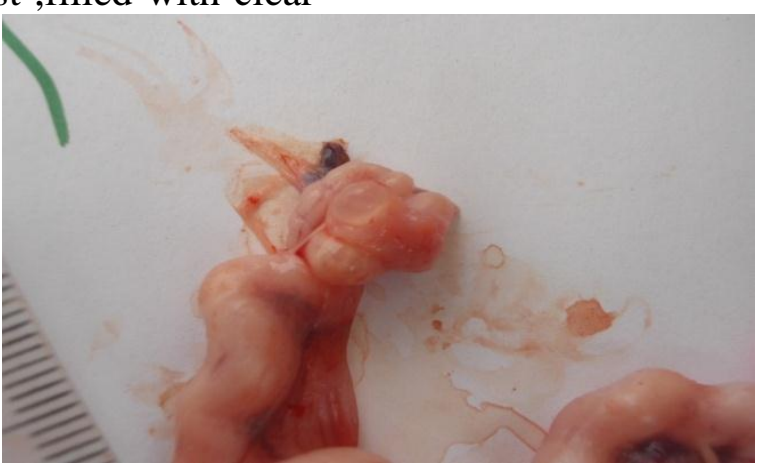

Figure (9) reveal the follicular cysts(arrow)

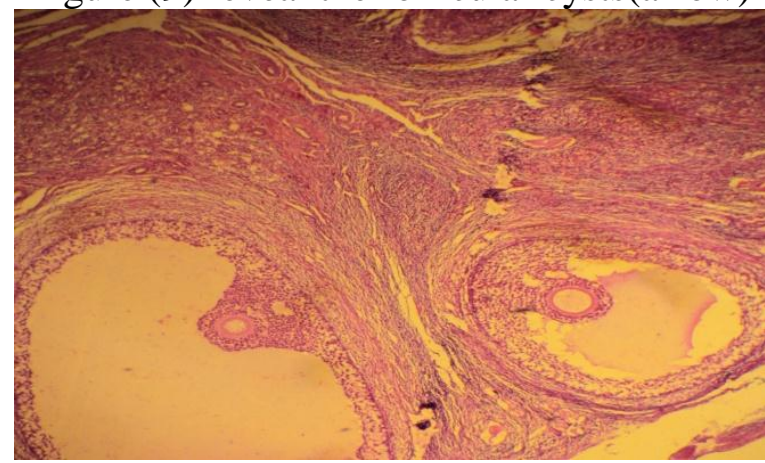

Figure (10) reveal presence of relatively large follicle (left) compared with normal follicle $(\mathrm{H}$ \&E.X100) .

\section{- Case (3): Pyometra}

The third case which reported in this study was pyometra, the captured queen was above one year old and weight about $4 \mathrm{~kg}$, the clinical examination revealed that the queen was healthy, after dissecting the animal ,the uterus was enlarged with congested appearance, figure 11. The color of the two uterine horns was abnormal and the endometrium was very congested.

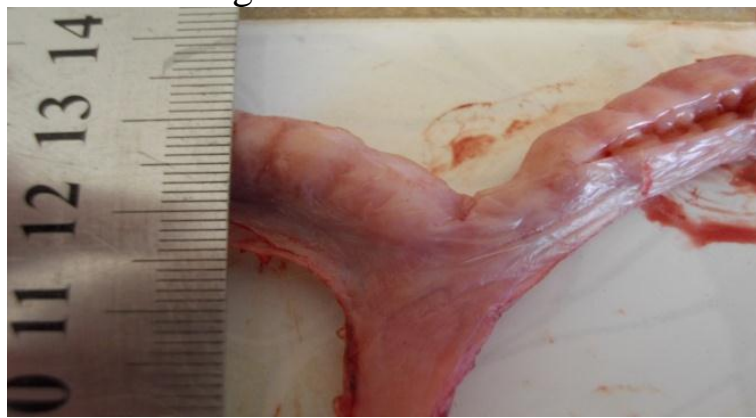

Figure (11) reveal the marked thickness of the endometrium and presence of cheesy pieces(arrow) 
The histopathological examination of the uterus with the endometritis reveal sever infiltration of neutrophils in sub epithelium and between the uterine glands, large number of necrotic neutrophils in the lumen of the uterine glands and uterine lumen and the exfoliation of the epithelium, figure 12 .
The histopathological appearance of the uterine tube reveal the dilation of the uterine tube and epithelial atrophy, infiltration of the epithelium, fusion of villi formed vacuole filled with pus and mucous, the lumen of the uterine tube filled with mucous

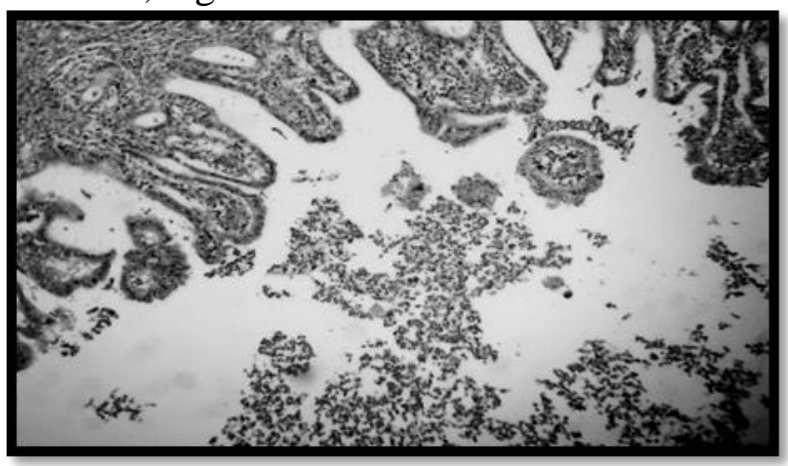

Figure (12) reveal sever infiltration of neutrophils in sub epithelium and between the uterine glands ,large number of necrotic neutrophils in the lumen of the uterine glands and uterine lumen and the exfoliation of the epithelium (arrow),(H\&E.X200)

The bacterial isolation and identification of exudates culturing reveals 2 isolates, one is $\mathrm{G}^{\text {-ve }}$ bacteria , the growing

\section{Discussion}

\section{Incidence of Sexual Activity}

Although several researchers refer to that in the tropical areas ,the domestic cat may breed throughout the year(5,6, $11)$,there are several factors may influence or determine breeding of domestic cat include length of day, environmental temperature and breed (12),so the fluctuation in breeding may vary from country to country . In temperate zone the high environmental temperature may decrease the estrous incidence(13),while (14) revealed that the effect of heat and humidity on domestic cat breeding depend on individual variation.

The present study was preformed along different 4 seasons on feral cat, which they are roaming outdoor and expose to natural irregular light as well as possibility of high individual variations existence, the fluctuation in incidence of follicular and luteal phases was frankly observed as shown in figure 1 and 2. on selective media, feature of colony and biochemical test reveal the characteristics of E.coli and Staphylococcus spp.

\section{Incidence of Sexual Inactivity}

The highest incidence period of anestrous in this study are in agreement with (15), that said it occurs in late Autumn months include October, November and December.other authors explained this as result of day light shortage under natural conditions(6).

The ovarian inactivity in Winter may be due to elevation of Prolactin and melatonin in circulating plasma $(6,16,17)$, while the relatively high incidence of anestrous phase in Summer may be due to increase of the environmental temperature as recorded by (18).

\section{Pregnancy and Pseudopregnancy}

The incidence rate of pregnancy which recorded in this study as demonstrated in figure 3 , are in agreement with (19) who reported that under the natural conditions the free ranging domestic cats can produce occasionally 3 litters /year, with 1-5 kitten in each litter, and the incidence of pregnancy is 
in marked contrast to pregnancy of bitch, which may breed only twice a year $(6,20)$.In this study ,the number of fetuses per each uterine horn, implantation rate, relationship between number of corpora lutea, number of fetuses, transuterine migration of embryos and the maximum number of embryos that migrate per animal are in agreement with (9).Little references are available about transuterine migration of embryos in domestic cat ,but it has been recorded in other litter bearing animals, (21) reported it in $40-50 \%$ of pregnant sows, while (22) observed it in $50 \%$ of pregnant bitches. All previous our data are near to that of (9) who recorded that the transutrine migration of embryos occurred from the side with ovary containing the greater number of CL to the side of fewer CL and the migration of embryos more than 3 embryo was not observed, while the migration rate recorded by the above authors was more than that recorded in this study, may be due to the difference in the number of examined cats between studies. The queens may undergo as many as 4-5 pseudopregnancies during the course of one poly estrus season (20) .In other hand (23) observed enlargement of abdomen with increase of appetite and weight gains in queens with pseudopregnancy, while (18) revealed that the average of duration of luteal activity in pseudopregnancy was 36.5 days. All these data are close to that obtained in present study where the pseudopregnancy was noted in 2 out of $17(11.76 \%$ ) queens with at least 2 active corpora lutea with slightly enlargement of uterus and the uterine tube.

\section{Vaginal Cytology}

The cyclical changes of vaginal exfoliated epithelium in canine have been extensively studied and are widely used clinically $(6,24)$, while only few reports are available on vaginal cytology in feline species.In the present study, the morphological changes of vaginal epithelium during estrus, phase are similar with that obtained by (15) and (25) documented that the number of superficial cells is fairly constant throughout behavior estrous and ranged from $40-60 \%$ of total cells present, and the vaginal cytology of diestrus phase are close to data of (26) which reported $50 \%, 48 \%$ and $2 \%$ for intermediate cells , parabasal cells and superficial nucleated cells respectively.Also, the rate of cells comprising the vaginal smear in anestrous queens are incompatible with finding of (24) noted that during anoestrus the cells are rare, mucus is obvious and a bund, and the majority of cells are basal or parabasal with some intermediate cells, while the present results are in agreement with (15) described that the exfoliated vaginal epithelial cells consist of less than $10 \%$ parabasal cells, $40 \%$ to $70 \%$ intermediate cells , and $30 \%$ to $40 \%$ nucleated superficial cells ,background debris is obvious .

\section{Hormonal Changes}

The hormonal assay in present study was revealed that the highest mean of serum estradiol was recorded in the follicular phase $47.5 \mathrm{pg} / \mathrm{ml}$, and it was $16 \mathrm{pg} / \mathrm{ml}$ during the recently ovulated queen, these finding are in agreement with (27) who recorded a concentration of 20-50 or higher during proestrous and estrus phases, and within the range of (20) who observed that the level of serum estradiol was increase from $25 \mathrm{pg} / \mathrm{ml}$ in first day of estrus to the peak $50 \mathrm{pg} / \mathrm{ml}$ in $5^{\text {th }}$ day, then decline to $10 \mathrm{pg} / \mathrm{ml}$ in the $10^{\text {th }}$ day.During the luteal phase the mean of progesterone level was $2 \mathrm{ng} / \mathrm{ml}$ in recently ovulated cat (with obvious corpus hemoragicum), increase to reach $48 \mathrm{ng} / \mathrm{ml}$ (range 22-56) in animals with diestrus (pregnancy and pseudopregnancy),these results are in disagreement with (15) they suspected the serum progesterone concentrations ranged from $1.5 \mathrm{ng} / \mathrm{ml}$ to more than $20 \mathrm{ng} / \mathrm{ml}$ in the queens with diestrus.All examined blood samples which obtained from the queens in anestrous phase reveal that the level of estrogen and progesterone at the basal level, these are 
compatible with levels mentioned by others (6,15).

\section{Pathological Study}

The relatively low incidence of reproductive problems in present study $(5 \%)$ might be due to small sample size, or due to fact, that the feral cat has short life comparable with household queens which receive more care and hygienic conditions. There were no available reference refer to recording of parovarian cyst in cat, except (28) explained that it arises either from remnant of the mesonephric (walffian) tubules or the paramesonephric (Mullarian) tubules. (29) suggested that many tiny parovarian cysts ranged $1-3 \mathrm{~cm}$ in diameter, are very common incidental finding in slaughtered cattle. (30) recorded two cases of parovarian cysts in Iraqi she camel.The size and description of follicular cyst was found in present study was in agreement with (20) and (28) they thought that the normal follicles of the queens is up $2-3 \mathrm{~mm}$ in diameter and the larger follicles are said to be cystic, and with (31) whose observed cysts as unilateral in 16 cats and bilateral in four from 20 cats. The prevalence of endometritis in cats increases with age in sexually intact female cats and mainly after parturition(32) ,these close to case was reported in this study, which was lactating ,over 1 years old queen .All observed gross and microscopical changes were compatible with description of $(32,33)$.The isolates of concurrent case (E.coli and Staphylococcus spp.) were in agreement with results of $(34,35)$, while (36) reported E.coli and Staphylococcus spp., as vaginal flora in various stages of queen estrous.

\section{References}

1. Wilson, D. E. and Reeder, D. M. (2005). Mammal Species of The World. A taxonomic and Geographic Reference. (editors). (3rd ed), Johns Hopkins University Press, p. 547.

2. James ,A.E.(1995).The Laboratory Cats. ANZCCART News,8(1) :1-2.

3. Pope ,C.E. ; Crichton ,M.G. ; Dumas, C. and Dresser ,B.(2004). Birth of Domestic Cat Kittens of Predetermined Sex After Transfer of Embryos Produced by Invitro Fertilization of oocytes with Flow Sorted Sperm .Theriogenology ,71(5):864-871.

4. McCumin ,D.M.; Bassert, J.M.( 2002) .Clinical Textbook for Veterinary Technicians, $5^{\text {th }}$ edition ,Philadelphia, W.B. Saunders Company, pp .310-315.

5. Fontbonne, A. and Malandain, E. (2006). Ovarian Ultrasonography and Follow up of Estrus in The Bitch and Queen ,WALTHAM . Focus , 16(2) :27-29.

6. Simpson ,G.M.; England, G.C.and Harvey, M. (eds).(2004).Manual of Small Animal Reproduction and Neonatology. Cheltenham, UK, British
Small Animal Veterinary Association Pub, pp. 11-16.

7. Luna ,L.G. (1968). Manual of Histological Staining Methods of the Armed Forces Institute of Pathology $.3^{\text {rd }}$ ED., MeGraw- HillBook Com. Newyork.

8. Collee ,J.G.; Miles ,R.S. and Watt ,B.(1996).Test for Identification of Bacteria. In: Practical Microbiology.14th .ed., Churchill Livingstone ,London.pp.131-149.

9. Tsutsui, T. ;Sakai, Y. ; Matsui, Y.;Sato, M. ;Yamane, I. ; Murao, I. and Stabenfeldt, G.H. (1989).Induced Ovulation in Cats Using Porcine Pituitary Gland Preparation During The non Breeding Season .Journal of Veterinary Sciences, 51 :677-683.

10. Steel, R.G.D. and Torrie, J.H. (1980). Principles and Procedures of Statistics . Abiomedical Approach ,2 ${ }^{\text {nd }}$ edi .MCG raw .Hill international book company.

11. Little, S.(2001). Reproduction abd Breeding Management in Cats . Veterinary Medicine ,96(7) : 549 -555. 
12. Eldredge, D.M.; Carlson, D.G.; Carlson, L.D. and Giffin, J.M.(2008). Cat Owner's Home Veterinary Hand Book. Wiley Publishing, Inc., Hoboken, New Jersey.

13. Feldman, E.C. and Nelson, R.W. (1996). Canine and Feline Endocrinology and Reproduction , $3^{\text {rd }}$ edition , Philadelphia ,WB Saunders Co, pp. 1016-1043.

14. Shille, V,M. ;Sojka, N.J. (1995) Feline Reproduction . In :Ettinger, S.J. and Feldman, E.C. (eds) .Text book of Veterinary Internal Medicine . Philadelphia , WB Saunders Co, p.1690.

15. Johnston ,S.D.; Root-Kustritz ,M.V.and Olson, P.N. (2001). Canine and Feline Theriogenology. Philadelphia: WB Saunders, pp. 389-474.

16. Leyva, H. ; Addiego, L. and Stabenfeldt, G. (1984). The Effect of Different Photoperiods on Plasma Concentrations of Melatonin, Prolactin and Cortisol in The Domestic Cat . Endocrinology, 115 :1729-1736.

17. Leyva, H. ;Madley, T. ;Stabenfeldt, G.H .(1989). Effect of Melatonin on Photoperiod Responses , Ovarian Secretion of Estrogen and Coital Responses in The Domestic Cat. Journal of Reproduction and Fertil. Suppl. ,39: 135 -142 .

18. Concannon, P.W. and Lein, D.H. (1983). Feline Reproduction .In: Kirk, R.W. (ed) :Current veterinary therapy VIII. Philadelphia ,WB Saunders Company ,p.932.

19. Pope, C.E . (2000).Embryo Technology in Conservation Efforts for Endangered Felids .Theriogenology,53:163-174.

20. Feldman ,E.C.and Nelson, R.W.( 2004). Canine and Feline Endocrinology and Reproduction. Feldman, (editors), Philadelphia ,WB Saunders, 3rd edition,pp 1016-1042.

21. Dziuk ,P.J.;Polge,C.P.;and Rowson ,L.E.A.(1964). Intrauterine Migration and Mixing Oembryos in Swine Following Egg Transfer .J.Anim. Sci., 23: $37-42$.

22. Tsutsui,T.(1975). Studies on The Reproduction in The Dog :VI. Ovulation Rate and Transuterine Migration of The Fertilized Ova .Jpn .J. Anim . Reprod. ,21:98-101.

23. Michael, A.F.; Nancy, S. and Jean, S(2008) .Cat Anatomy and Physiology . Washongton ,4-H cat project .unit 3.EM4289E., pp.20-24.

24. Mills, J.N. ;Valli,V.E. ;Lumsden,J.H .(1979).Cyclical Changes of Vaginal Cytology in The Cat .Canadian Veterinary Journal 20:95-101.

25. Shille, V.M. ; Lundstrom ,K.E. and Stabenfeldt, G.H.(1979). Follicular Function in The Domestic Cat as Determined by Estradiol $-17 \quad \beta$ Concentrations in Plasma : Relation to Estrus Behavior . Biology of Reproduction, 21:953-963.

26. Tsutsui, T. and Stabenfeldt, G.H.(1993). Biology of Ovarian Cycles,Pregnancy and Pseudopregnancy in The Domestic Cat. Journal of Reproduction and Fertility supplement,47:29-35.

27. Long,S.(2006).Genetics\& Reproduction Physiology of Dog and Cats .Philadelphia, WB Saunders Co,pp.8186.

28. McEntee, K. (1990). Reproductive Pathology of Domestic Mammals . Academic Press,p. 171.

29. Noaks ,D.E.; Parkinson ,T.J.; England ,G.C.W.(2003).Arthur's Veterinary Reproduction and Obstetrics. Philadelphia, WB Saunders Co,pp.3740.

30. Al- Delemi, D.H.(2007). Anatomical. Physiological, Bacteriological and Pathological study in Iraqi She Camels. Doctoral Thesis. Vet. Med. College , University of Baghdad , Iraq.

31. Gelberg, H.B.; McEntee, K. and Heath, E.H. (1984). Feline Cystic Rete Ovarii. Veterinary Pathology ,21: 304-307. 
32. 32.Potter, K. ; Hancook, D.H. and Gallina, A.M. (1991). Clinical and Pathological Features of Endometrial Hyperplasia , Pyometra and Endometritis in Cats :79 cases (19801985) . Journal of American Veterinary Medicine Association, 198 (8) : 1

33. Misirlioglu, D. ; Nak, D. ; Sevimli, N. ; Nak, Y. ; Ozyigit, M.O. ; Akkoc, A. and Cangul, I.T .(2006) .Steroid Receptor Expression and HER -2 /neu (c-erB -2) Oncoprotein in The Uterus of Cats with Cystic Endometrial Hyperplasia Pyometra Complex . Journal of Veterinary Medicine A Physiological and Pathological Clinical Medicine, (5) : 225-229 .
34. Davidson ,A.P.; Feldman ,E.C. and Nelson, R.W.(1992). Treatment of Pyometra in Cat, Using Prostaglandin F2 $\alpha: 21$ Cases (1982-1990) . Journal of American Veterinary Medicine Association ,200:825-828.

35. Kenney, K.J.; Matthiesen, D.T.; Brown, N.O.and Bradley, R.L. (1987). Pyometra in Cats: 183 Cases (19791984). Journal of American Veterinary Medicine Association,191(9):11301132.

36. Patricia,C. S.; Jones ,R.L.; Kesel, M.L. and Olson ,P.N.(1999). Normal Bacterial Flora in Canine and Feline Uteri .J. Vet. Diagn. Invest., 11: 560562.

\section{دراسة بعض الجوانب الفسلجية والمرضية لجهاز تناسل القطط السائبة في العراق

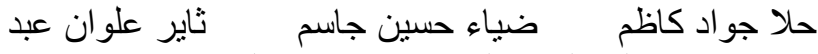 كلية الطب البيطري / جامعة القادسية

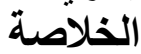

أجريت الدر اسة الحالية لمعرفة بعض جوانب التكاثر في القطط السائبة في العر اق ، حيث جمعت 60 عينة دم وجهاز تناسلي من إناث قطط تم اصطيادها للفترة من تشرين الثاني 2008 إلى نشرين الثاني 2009. الدراستة إن معدل حدوث إناث الطور الجريبي هو

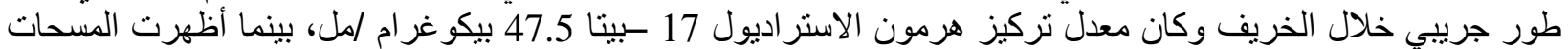

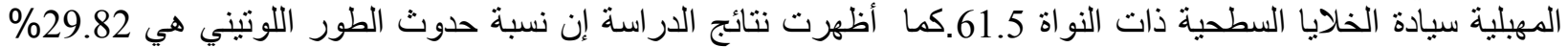

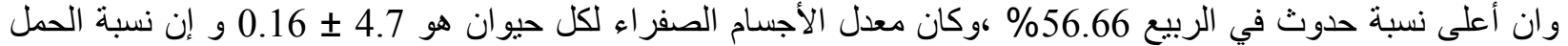

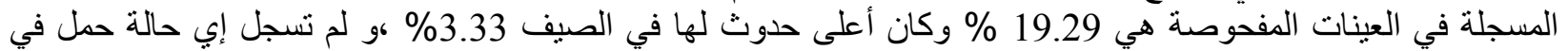

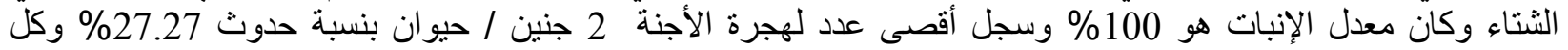

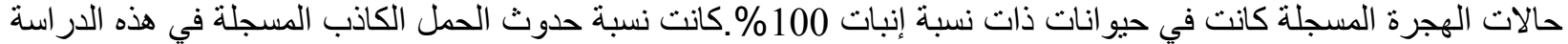

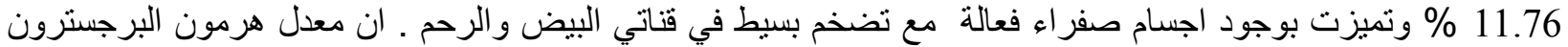

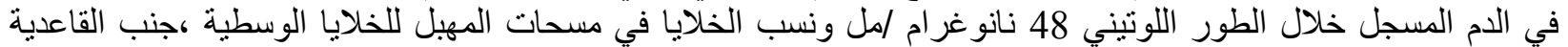

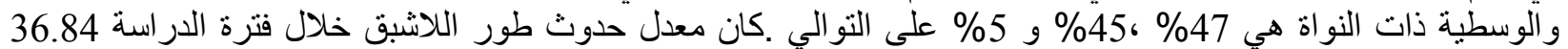

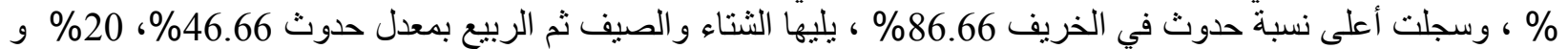

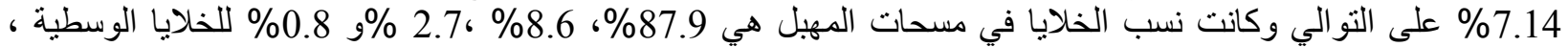

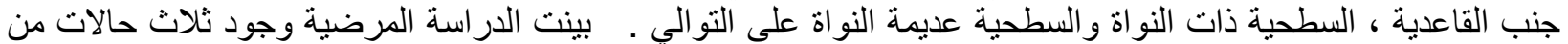

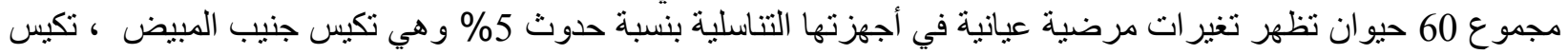
المبايض الجريبي وتقيح الرحم. 